\title{
PENGARUH FERMENTASI TERHADAP KANDUNGAN PROTEIN DAN ASAM AMINO PADA TEPUNG GAPLEK YANG DIFORTIFIKASI TEPUNG KEDELAI (Glycine max (L))
}

\author{
The Effect of Fermentation on Protein Content and Amino Acids of Fortified Dried-Cassava Flour-Soybean \\ (Glycine Max (L)) Flour
}

Yohanes Martono, Lucia Devi Danriani, Sri Hartini

\author{
Program Studi Kimia, Fakultas Sains dan Matematika, Universitas Kristen Satya Wacana, \\ Jl. Diponegoro No. 52-60, Salatiga \\ Email: yohanes.martono@staff.uksw.edu
}

\begin{abstract}
ABSTRAK
Peningkatan kadar protein dan pengayaan asam amino dalam tepung gaplek dapat dilakukan dengan cara fortifikasi tepung gaplek dengan tepung kedelai melalui fermentasi. Tujuan dari penelitian ini adalah membandingkan kandungan protein terlarut antara tepung gaplek tidak terfortifikasi dan terfortifikasi tepung kedelai pada beberapa waktu fermentasi dan mengidentifikasi asam amino yang terkandung dalam tepung gaplek dan tepung gaplek terfortifikasi. Metode penelitian meliputi pembuatan tepung gaplek terfortifikasi secara fermentasi dengan rasio penambahan tepung kedelai $25 \mathrm{~g}$ dan kapang $5 \mathrm{~g}$ dari $100 \mathrm{~g}$ gaplek yang kemudian difermentasi selama 40 jam. Kadar protein ditentukan menggunakan metode Biuret sedangkan identifikasi asam amino menggunakan metode Kromatografi Lapis Tipis (KLT) dan Kromatografi Cair Kinerja Tinggi (KCKT). Rancangan percobaan penelitian menggunakan Rancangan Acak Kelompok (RAK). Sebagai perlakuan adalah gaplek kontrol (tidak terfortifikasi tepung kedelai) pada jam ke-0 (G0); 20 jam (G20); 40 jam (G40) dan gaplek terfortifikasi pada jam ke-0 (GF0); 20 jam (GF20); dan 40 jam (GF40). Sebagai kelompok adalah waktu analisis. Data rata-rata kadar protein terlarut dibandingkan dengan uji Beda Nyata Jujur (BNJ) dengan tingkat kebermaknaan 5\%. Hasil penelitian ini menunjukkan bahwa kadar protein terlarut pada fermentasi selama 40 jam lebih tinggi dibandingkan 20 jam dan 0 jam, dengan nilai 22,68\%, 20,96\%, dan 18,70\% secara berurutan. Berdasarkan hasil identifikasi KLT dan KCKT, asam amino dalam tepung gaplek terfortifikasi adalah aspartat, glutamat, serin, histidin, glisin, arginin, alanin, tirosin, metionin, valin, isoleusin, dan lisin.
\end{abstract}

Kata kunci: Gaplek, fortifikasi, fermentasi, protein, asam amino

\begin{abstract}
Enhancement of proteins and enrichment of amino acids of dried cassava flour can be carried out by fermentation of dried cassava and soy-flour mixture. The purposes of this study were to compare soluble protein's content and to identify amino acids in fortified dried-cassava flour. The methods involved were making fortified dried-cassava flour with ratio of $25 \mathrm{~g}$ (soy-flour) and $5 \mathrm{~g}$ (yeasts) of 100 grams dried-cassava and fermentation of the mixture for $40 \mathrm{~h}$, measuring soluble protein's content by biuret assay and identifying amino acids using Thin Layer Chromatography (TLC) and High Performance Liquid Chromatography (HPLC). Research design used Randomized Completely Block Design (RCBD). Treatments applied were unfortified dried cassava flour at 0 hour (G0); 20 hour (G20); 40 hour (G40) and fortified dried cassava flour at 0 hour (GF0); 20 hour (GF20) and 40 hour (GF40). As group was analyisis time. Data of soluble protein content were analyzed using ANNOVA. The Honestly Significant Differences (HSD) test at 5 $\%$ level of significance was used to compare the treatments mean. The results showed that the soluble protein's content of 40 hours fermentation was higher than of 20 hours fermentation and the latter was higher than 0 hour fermentation, with values of $22.86 \%, 20.96 \%$, and $18.70 \%$, respectively. Based on TLC and HPLC identification, the amino acids in fortified dried-cassava flour, were aspartate, glumatate, serine, histidine, glicine, arginine, alanine, tyrosine, methionine, valine, isoleusine, leusine, and lysine.
\end{abstract}

Keywords: Dried-cassava, fortification, fermentation, protein, amino-acid 


\section{PENDAHULUAN}

Konsumsi terigu masyarakat Indonesia selama Januari - September 2011 naik sebesar 5,81\% bila dibandingkan dengan tahun 2010. Dalam rangka memenuhi kebutuhan terigu, pemerintah melakukan impor terigu dari luar negeri. Menurut Badan Pusat Statistik, impor terigu Indonesia dari Januari - Agustus 2011 sudah mencapai 433.429 ton (Rosallina, 2011). Salah satu alternatif untuk mengatasi masalah ketahanan pangan ini adalah dengan diversifikasi pangan berbasis bahan pangan lokal. Hal tersebut juga sesuai dengan Peraturan Presiden Nomor 22 Tahun 2009 tentang Kebijakan Percepatan Penganekaragaman Konsumsi Pangan Berbasis Sumberdaya Lokal yang ditindaklanjuti oleh Peraturan Menteri Pertanian (Permentan) No. 43 Tahun 2009 tentang Gerakan Percepatan Penganekaragaman Konsumsi Pangan (P2KP) Berbasis Sumber Daya Lokal. Peraturan tersebut menjadi acuan yang dapat mendorong percepatan penganekaragaman konsumsi pangan berbasis sumber daya lokal (Kementerian Pertanian, 2012).

Salah satu sumber daya lokal yang berpotensi dikembangkan adalah ubi kayu. Produktivitas ubi kayu di Indonesia adalah 15-20 juta ton/tahun (Kementerian Pertanian, 2012). Gaplek merupakan salah satu olahan ubi kayu (tanaman lokal) yang dikeringkan dengan energi yang dihasilkan sebesar 338 kilokalori namun kandungan protein hanya sebesar 1,5 gram per 100 gram tepung gaplek (Rukmana, 1997). Protein merupakan salah satu kriteria untuk menentukan nilai gizi bahan makanan. Pengayaan protein dapat dilakukan melalui proses fermentasi (Boonnop dkk., 2009). Melalui fermentasi ini terjadi perombakan senyawa kompleks protein menjadi senyawa-senyawa yang lebih sederhana dan memiliki daya cerna amat tinggi seperti asam amino bebas (Onweluzo dan Nwabugwu, 2009; Amodou dkk., 2010). Untuk lebih meningkatkan kandungan protein terlarut, tepung gaplek dapat difermentasi (Aro, 2008; Ezekiel dkk., 2010) dan lebih jauh difortifikasi dengan tepung kedelai (Ugwuona dkk., 2012). Oleh karena itu, kombinasi proses fermentasi dan fortifikasi tepung gaplek dengan tepung kedelai diharapkan dapat lebih meningkatkan kualitas tepung.

Berdasarkan penelitian sebelumnya (Maidawati dkk., 2011), kondisi optimum dalam pembuatan tepung gaplek terfortifikasi adalah tepung gaplek difermentasi dengan tepung kedelai dan ragi (25:5) selama 42,12 jam. Pada kondisi ini, kadar protein terlarut yang dihasilkan adalah sebesar 9,00\%. Namun, pada penelitian sebelumnya ini belum dilakukan identifikasi asam amino pada tepung gaplek terfortifikasi. Mutu protein juga dinilai dari kandungan asam amino pada suatu bahan pangan (Onabanjo dkk., 2008).

Selama proses fermentasi kedelai menggunakan bakterial Douchi, protein kedelai akan terdegradasi menjadi asam amino dan protein terlarut akan meningkat (Li dkk., 2007). Protein terlarut merupakan oligopeptida dan terdapat rantai kurang dari 10 asam amino, serta memiliki sifat mudah diserap oleh sistem pencernaan (Purwoko dan Handajani, 2007). Kualitas kandungan protein dapat ditentukan oleh derajat cerna protein dan komposisi asam amino khususnya asam amino esensial yang mudah dicerna tubuh (Onyango dkk., 2005; Chen dkk., 2010). Protein kedelai mengandung 9 jenis asam amino esensial, yaitu: sistein, isoleusin, leusin, lisin, metionin, fenilalanin, treonin, triptofan dan valin (Amodou dkk., 2010). Berdasarkan latar belakang di atas, maka penelitian ini bertujuan untuk membandingkan kadar protein terlarut antara tepung gaplek dengan tepung gaplek terfortifikasi pada beberapa waktu fermentasiserta mengidentifikasi jenis asam amino yang terkandung dalam tepung gaplek dan tepung gaplek terfortifikasi.

\section{METODE PENELITAN}

\section{Bahan dan Alat}

Singkong yang digunakan adalah varietas Gatot Kaca yang didapatkan dari daerah Salatiga. Kedelai yang digunakan adalah kedelai (Glycine max (L)) varietas Galunggung dan ragi yang digunakan adalah agi Ra-prima (PT. Aneka Fermentasi Industri) yang diperoleh dari Pasar Raya Salatiga. Adapun bahan kimia yang digunakan adalah $\mathrm{NaOH}$, $\mathrm{CuSO}_{4} \cdot 5 \mathrm{H}_{2} \mathrm{O}, \mathrm{NaK}$-Tartat, akuades, $\mathrm{HCl}$, butanol, asam asetat glasial, ninhydrin, etanol, $\mathrm{HCN}$, tetrahidrofuran(THF), ortophaldehid, leusin, fenilalanin, metionin, sistein, lysinmonochloryde, dan treonin (Merck-Germany).

Alat yang digunakan antara lain: drying cabinet, grinder, ayakan aperture $250 \mu \mathrm{m}$-mesh no. 60 , centrifuge (EBA 21 Hettich Zentrifugen), kertas saring, Spektrofotometer (Optizen UV 2120), kuvet, alat reflux, Plat KLT (Silica Gel 60 F 254 (Merck-Germany)), chamber, waterbath, Neraca Acis AD-600H, kertas saring Whatman 0,2 c, kromatografi cair kinerja tinggi (Shimadzu LC 10), dan piranti gelas.

\section{Pembuatan Gaplek (Maidawati dkk., 2011)}

Singkong dibersihkan lalu dipotong kecil-kecil, selanjutnya potongan singkong direndam dengan air garam selama 1 malam. Potongan singkong kemudian dikeringkan dalam drying cabinet pada suhu $50^{\circ} \mathrm{C}$ selama 1 malam dan setelah kering gaplek siap untuk perlakuan berikutnya.

\section{Pembuatan Tepung Gaplek Terfortifikasi (Maidawati dkk., 2011)}

Gaplek kering dikukus selama 30 menit, kemudian didinginkan. Setelah dingin, gaplek ditambah 5\% ragi dan $25 \mathrm{~g}$ tepung kedelai dari 100 gram gaplek kering dan 
difermentasikan dengan lama waktu 0, 20, dan 40 jam pada suhu ruang. Gaplek terfermentasi dikeringkan dalam drying cabinet dan setelah kering, gaplek terfermentasi dihaluskan dengan menggunakan grinder dan diayak dengan ayakan aperture $250 \mu \mathrm{m}$, mesh no. 60 . Sebagai kontrol adalah tepung gaplek yang tidak difortifikasi dan difermentasi dengan $5 \mathrm{~g}$ ragi pada waktu dan suhu fermentasi yang sama dengan tepung gaplek yang difortifikasi.

\section{Penentuan Kadar Protein Tepung Gaplek Terfortifikasi dengan Metoda Biuret (AOAC, 1995)}

Pembuatan kurva standar Biuret. Reagen Biuret dibuat dengan melarutkan $0,15 \mathrm{~g} \mathrm{CuSO}_{4} \cdot 5 \mathrm{H}_{2} \mathrm{O}+0,6 \mathrm{~g}$ NaKTatrat dalam labu ukur $50 \mathrm{~mL}$. Kemudian larutan dimasukkan dalam labu ukur $100 \mathrm{~mL}$, selanjutnya ditambah $30 \mathrm{~mL} \mathrm{NaOH} \mathrm{10 \%} \mathrm{dan} \mathrm{digenapkan} \mathrm{akuades.}$

Larutan protein (BSA) dengan konsentrasi $10 \mathrm{mg} / \mathrm{ml}$ disiapkan untuk pembuatan kurva standar Larutan protein tersebut disiapkan dengan cara meningkatkan konsentrasinya yaitu 1, 2, 3, 4, 5, 6, 7, 8, 9, $10 \mathrm{mg} /{ }_{\mathrm{ml}}$ dalam 0,5 mL. Kemudian masing-masing larutan ditambahkan $2 \mathrm{ml}$ reagen Biuret ke dalam setiap tabung dan larutan dihomogenisasi lalu diinkubasi selama 30 menit pada suhu kamar. Masing-masing absorban larutan diukur dengan spektrofotometer pada panjang gelombang $550 \mathrm{~nm}$.

Pengukuran sampel. Satu gram sampel ditambah akuades dan $1 \mathrm{~mL} \mathrm{NaOH} 1 \mathrm{M}$, kemudian dipanaskan di dalam water bath dengan suhu $90^{\circ} \mathrm{C}$ selama 10 menit. Setelah itu larutan dipusingkan selama 10 menit. Setengah mililiter larutan supernatan diambil dan dimasukkan ke dalam tabung reaksi. Dua mililiter reagen Biuret ditambahkan ke dalam tabung reaksi tersebut. Setelah itu di inkubasi selama 30 menit pada suhu kamar. Kemudian absorbansi sampel diukur dengan spektrofotometer pada panjang gelombang $550 \mathrm{~nm}$.

\section{Identifikasi Asam Amino dengan Kromatografi Lapis Tipis (KLT) (Rohmer, 1991)}

Preparasi sampel. Tujuh puluh lima gram sampel dihidrolisis dengan $\mathrm{HCl}$ 7,5 M selama 4 jam pada suhu $\pm 90^{\circ} \mathrm{C}$ menggunakan pelarut $\mathrm{HCl}$ 7,5 M. Hasil hidrolisis disaring untuk menghilangkan kotoran.

Identifikasi asam amino. Hidrolisat ditotolkan pada plat KLT (Silica Gel F254 sebagai fase diam) lalu dielusikan di dalam chamber yang telah dijenuhkan. Fase gerak yang digunakan adalah butanol: asam asetat glasial: aquades dengan perbandingan 4:1:1 (v/v/v). Standar asam amino yang digunakan sebagai pembanding adalah lisin, metionin, leusin, sistein, fenilalanin, treonin.

\section{Identifikasi Asam Amino dengan Kromatografi Cair Kinerja Tinggi (KCKT) (Mursyid dan Zuprizal, 2005)}

Preparasi sampel. Enam puluh miligram sampel ditambah $4 \mathrm{ml} \mathrm{HCl} 6 \mathrm{M}$, kemudian dipanaskan selama 24 jam dengan suhu $110{ }^{\circ} \mathrm{C}$. Selanjutnya hasil hidrolisis dinetralkan dengan $\mathrm{NaOH} 6 \mathrm{M}$ hingga $10 \mathrm{ml}$ dan disaring dengan kertas saring Whatman 0,2 c. Dua puluh lima mikroliter sampel ditambah larutan OPA (Ortophalaldehid) sebanyak 300 $\mu \mathrm{L}$ dan diaduk selama 5 menit. Selanjutnya, $20 \mu \mathrm{L}$ sampel dimasukkan ke dalam injektor KCKT.

Analisis sampel. Analisis sampel secara KCKT dilaksanakan di Laboratorium Kimia Organik Jurusan Kimia Fakultas MIPA Universitas Gadjah Mada, Yogyakarta. Sampel dianalisis dengan menggunakan kromatografi cair kinerja tinggi (Shimadzu LC 10) pada fase diam kolom Licrospher ( 100 RP 18 (125 x 4 mm, $5 \mu \mathrm{m})$. Sebagai fase gerak adalah Eluent A: metanol: $50 \mathrm{mM}$ natrium asetat: Teterahidrofuran (THF) dan Eluent B:65\% metanol. Analisis ini dilakukan pada suhu $27^{\circ} \mathrm{C}$ dengan kecepatan alir $1 \mathrm{ml} / \mathrm{menit}$ serta dideteksi dengan detektor fluorosen pada panjang gelombang 360 dan $460 \mathrm{~nm}$. Standar asam amino yang digunakan sebagai pembanding adalah asam aspartat, glutamat, serin, histidin, glisin, arginin, alanin, tirosin, metionin, valin, isoleusin, leusin, lisin, dan fenilalanin.

\section{Analisis Data}

Rancangan percobaan pada penelitian ini menggunakan Rancangan Acak Kelompok (RAK) dengan 6 perlakuan dan 4 kali ulangan. Sebagai perlakuan adalah tepung gaplek tidak terfortifikasi yang difermentasi pada 0 jam (G0), 20 jam (G20), 40 jam (G40) dan tepung gaplek terfortifikasi pada lama waktu fermentasi 0 jam (GF0), 20 jam (GF20), dan 40 jam(GF40). Sedangkan sebagai kelompok adalah waktu analisis. Purata antar perlakuan diuji menggunakan Uji Beda Nyata Jujur (BNJ) dengan tingkat kebermaknaan 5\%. Data hasil KLT dan KCKT dianalisis secara deskriptif.

\section{HASIL DAN PEMBAHASAN}

\section{Peningkatan Kadar Protein Terlarut Tepung Gaplek Terfortifikasi}

Selama proses fermentasi terjadi peningkatan kadar protein terlarut pada tepung gaplek terfortifikasi sedangkan pada kontrol (tepung gaplek yang hanya ditambah ragi) relatif sama. Masing-masing kadar protein terlarut pada tepung gaplek terfortifikasi maupun tepung gaplek yang hanya ditambah ragi dapat dilihat pada Tabel 1. Kurva perubahan kadar protein terlarut antara kontrol (gaplek ditambah ragi) dan gaplek terfortifikasi pada berbagai lama fermentasi ditunjukkan pada Gambar 1. 
Tabel 1. Kadar protein terlarut $(\% \pm \mathrm{SE}) \quad(\mathrm{b} / \mathrm{b}$, berat kering) tepung gaplek kontrol dan tepung gaplek terfortifikasi

\begin{tabular}{llllll}
\hline G0 & G20 & G40 & GF0 & GF20 & GF40 \\
\hline $2,13 \pm 0,14^{\mathrm{a}}$ & $2,30 \pm 0,36^{\mathrm{a}}$ & $2,70 \pm 0,54^{\mathrm{a}}$ & $18,70 \pm 0,25^{\mathrm{b}}$ & $20,96 \pm 0,65^{\mathrm{c}}$ & $22,86 \pm 1,02^{\mathrm{d}}$ \\
\hline
\end{tabular}

Keterangan:

*Huruf yang berbeda menyatakan adanya perbedaan secara nyata.

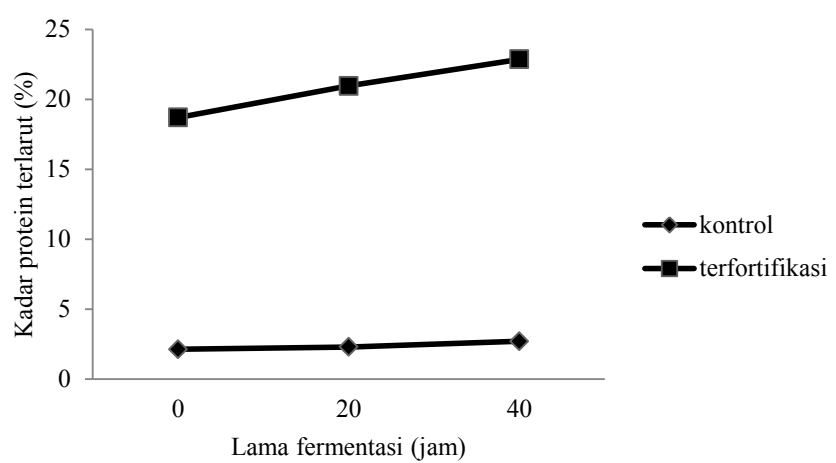

Gambar 1. Kurva perubahan kadar protein terlarut antara kontrol (gaplek ditambah ragi) dan gaplek terfortifikasi tepung kedelai pada berbagai lama fermentasi

Pada sampel G0, G20, dan G40 tidak terjadi perbedaan kadar protein antara masing-masing sampel. Hal tersebut dikarenakan terbatasnya sumber nitrogen pada gaplek yang digunakan oleh mikroorganisme selama fermentasi, sehingga, fermentasi yang dilakukan dari 0 hingga 40 jam tidak menyebabkan kenaikan kadar protein terlarut G0, G20, dan G40 yang signifikan. Namun antara sampel G0G20-G40 dan GF0-GF20-GF40 terjadi perbedaan kadar protein terlarut diantara sampel tersebut. Hal ini dikarenakan adanya sumber nitrogen lain (selain tepung gaplek maupun ragi) yaitu protein tepung kedelai bagi pertumbuhan mikroba selama proses fermentasi (Ezekiel dkk., 2010). Kadar protein terlarut GF40 menunjukkan hasil yang lebih tinggi dari GF20 dan lebih tinggi dari GF0.Hal ini menunjukkan bahwa terjadi peningkatan kadar protein terlarut seiring dengan lama waktu fermentasi. Hasil ini selaras dengan penelitian sebelumnya (Oboh dan Elusiyan, 2007; Aro dan Aletor, 2012; Li dkk., 2007; Adamafio dkk., 2010; Maidawati dkk., 2011) yang menunjukkan bahwa kadar protein meningkat seiring dengan lama waktu fermentasi.

Peningkatan kadar protein terlarut dapat dikarenakan selama proses fermentasi, mikroba menghidrolisis protein kompleks menjadi asam amino bebas atau peptida yang lebih sederhana dengan adanya aktivitas enzim proteolitik (Onweluzo dan Nwabugwu, 2009; Amadou dkk., 2010). Selain itu, peningkatan biomasa mikroba selama proses fermentasi seiring dengan sekresi beberapa enzim ekstraseluler (protein terlarut) dan protein sel tunggal sehingga kandungan protein terlarut menjadi meningkat (Oboh dan Elusiyan, 2007).
Kandungan protein terlarut pada GF40 dan GF20 (Tabel 1) juga menunjukkan hasil yang lebih tinggi dari kadar protein terlarut tepung terigu " $X$ " yaitu 20,25\%. Tepung gaplek terfortifikasi yang dihasilkan pada penelitian ini juga memiliki kadar protein terlarut yang lebih tinggi daripada hasil penelitian Maidawati dkk. (2011) (9,00\%). Hal tersebut dikarenakan perbedaan penggunaan jenis kedelai pada penelitian Maidawati dkk. (2011).

Kadar protein terlarut atau sering disebut daya cerna protein merupakan kemampuan suatu protein untuk dihidrolisis menjadi asam amino oleh enzim-enzim pencernaan (protease). Daya cerna protein adalah salah satu faktor yang menentukan mutu protein karena menentukan ketersediaan asam amino secara biologis. Daya cerna yang rendah berarti protein yang masuk ke tubuh tidak dapat larut atau dicerna dengan sempurna sehingga asam-asam amino yang terkandung tidak dapat larut dan digunakan oleh tubuh. Hal ini dapat menurunkan mutu protein suatu makanan (Campbell, 1992). Kondisi pertumbuhan mikroba pada fermentasi gaplek dan gaplek terfortifikasi kedelai dapat dilihat pada Gambar 2.

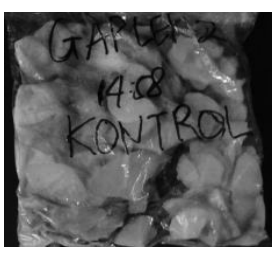

[A]

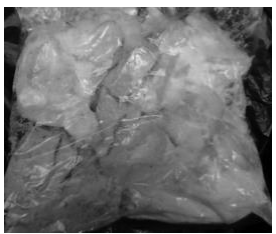

[D]

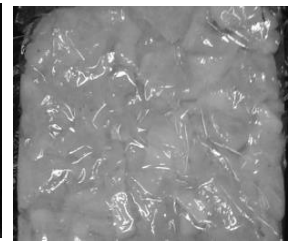

[B]

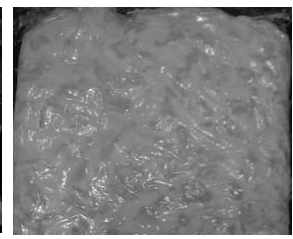

[E]

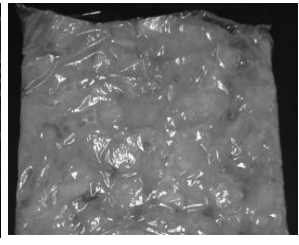

[C]

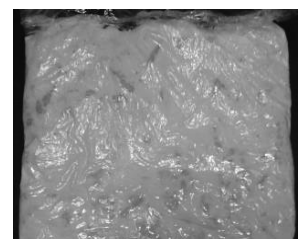

[F]
Gambar 2. Kondisi pertumbuhan mikroba pada [A] G0; [B] G20; [C] G40; [D] GF0; [E] GF20; dan [F] GF40

\section{Identifikasi Asam Amino dengan Kromatografi Lapis Tipis (KLT)}

Mutu protein suatu bahan makanan ditentukan komposisi dan ketersediaan asam amino yang dapat diserap oleh tubuh (Chen dkk., 2010; Amodou dkk., 2010). Susunan asam amino pada tepung gaplek yang hanya ditambah ragi, tepung gaplek terfortifikasi dan tepung kedelai mengalami perubahan. Komposisi susunan tersebut dapat dilihat pada Tabel 3, sedangkan profil KLT identifikasi asam amino dapat dilihat pada Gambar 3 .

Berdasarkan Tabel 2, asam amino pada tepung gaplek terfortifikasi yang teridentifikasi adalah sistein, treonin, 
Tabel 2. Nilai Rf asam amino standar, kedelai, gaplek, tepung gaplek yang ditambah ragi, dan tepung gaplek terfortifikasi

\begin{tabular}{|c|c|c|c|c|c|c|c|c|}
\hline A.A Std & Ked & G & G0 & G20 & G40 & GF0 & GF20 & GF40 \\
\hline 0,11 (Lys) & - & - & - & - & - & - & - & - \\
\hline 0,14 (Cys) & 0,14 (Cys) & - & - & - & - & 0,14 (Cys) & 0,14 (Cys) & 0,14 (Cys) \\
\hline 0,35 (Tre) & 0,32 (Tre) & 0,30 (Tre) & 0,34 (Tre) & 0,34 (Tre) & 0,34 (Tre) & 0,30 (Tre) & 0,30 (Tre) & 0,30 (Tre) \\
\hline 0,59 (Met) & 0,60 (Met) & - & 0,59 (Met) & 0,59 (Met) & 0,59 (Met) & 0,58 (Met) & 0,59 (Met) & 0,58 (Met) \\
\hline 0,68 (Leu) & $0,68(\mathrm{Leu})$ & - & - & - & - & $0,65(\mathrm{Leu})$ & - & $0,65(\mathrm{Leu})$ \\
\hline 0,71 (Phe) & 0,76 (Phe) & - & - & - & - & - & - & - \\
\hline- & 0,25 (Asp*) & 0,42 (Cys*) & - & - & - & 0,38 (Cys*) & 0,37 (Cys*) & 0,38 (Cys*) \\
\hline- & 0,40 (Cys*) & 0,53 (Met*) & - & - & - & - & 0,51 (Met*) & - \\
\hline- & 0,81 & - & - & - & - & - & - & - \\
\hline
\end{tabular}

Keterangan: A.A Std = Asam Amino Standar, Ked = Kedelai, G $=$ Gaplek, Lys $=$ Lisin, Tre $=$ treonin, Met $=$ Metionin, Cys $=$ Sistein, Phe $=$ Fenilalanin, Leu $=$ Leusin. * Perbandingan Rf sampel dengan Rf asam amino literatur

metionin, dan leusin. Adapun pada tepung gaplek kontrol adalah treonin dan metionin. Perubahan asam amino ini dimungkinkan diakibatkan adanya pembentukan enzim protease oleh mikroorganisme yang dapat menghidrolisis protein sehingga terjadi perubahan kandungan asam aminonya selama fermentasi. Hasil ini selaras dengan penelitian Omafuvbe (2006) yang menunjukkan adanya aktivitas hidrolisis protein oleh protease menjadi asam amino bebas pada fermentasi kedelai menggunakan Bacillus subtilis.

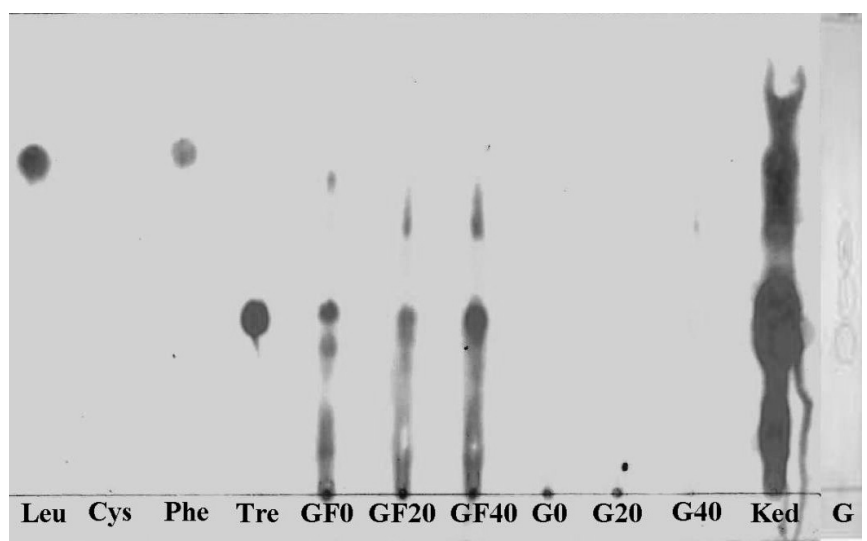

Gambar 3. Hasil kromatografi lapis tipis standar asam amino, tepung gaplek kontrol, tepung gaplek terfortifikasi, tepung kedelai, dan gaplek

Pada proses fermentasi ini juga terjadi pengurangan jumlah asam amino dari tepung kedelai menjadi tepung gaplek terfortifikasi. Hilangnya asam amino ini mungkin juga disebabkan oleh proses deaminasi. Proses deaminasi adalah proses pemecahan (hidrolisis) asam amino menjadi asam keto dan ammonia $\left(\mathrm{NH}_{4}^{+}\right)$. Salah satu hasil deaminasi ini adalah senyawa nonnitrogen $(\mathrm{C}, \mathrm{H}$, dan $\mathrm{O})$ yang digunakan sebagai sumber energi untuk pertumbuhan mikroba. Hal ini didasari oleh penelitian Omafuvbe (2006) yang menunjukkan adanya peningkatan kadar amonia pada fermentasi kedelai selama 48 jam pertama oleh Bacillus subtilis sebagai hasil peningkatan aktivitas proteolitik dan melepaskan ammonia hasil deaminasi asam amino.

Pengayaan jumlah asam amino juga terjadi pada tepung gaplek kontrol menjadi tepung gaplek terfortifikasi selama proses fermentasi. Asam amino baru yang teridentifikasi setelah proses fermentasi adalah leusin dan sistein. Hasil ini juga selaras dengan penelitian yang dilakukan oleh Aro dan Aletor (2012) yang menunjukkan selama proses fermentasi terjadi pengayaan asam amino pada kulit ubi kayu.

\section{Identifikasi Asam Amino dengan Kromatografi Cair Kinerja Tinggi (KCKT)}

Identifikasi perubahan asam amino pada tepung gaplek terfortifikasi selama proses fermentasi diperkuat

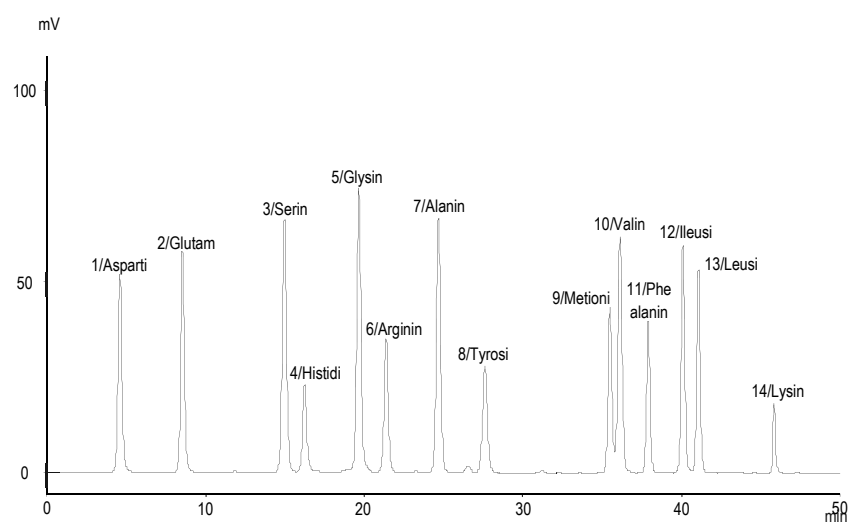

Keterangan: Standar dianalisis pada fase diam kolom Licrospher ${ }^{\circledR} 100$ RP $18(125 \times 4 \mathrm{~mm}, 5 \mu \mathrm{m})$ dan fase gerak adalah Eluent A : metanol : $50 \mathrm{mM}$ natrium asetat : Teterahidrofuran (THF) dan Eluent B :65\% metanol. Suhu analisis adalah $27^{\circ} \mathrm{C}$ dengan kecepatan alir $1 \mathrm{ml} /$ menit serta dideteksi dengan detektor fluorosen pada panjang gelombang 360 dan $460 \mathrm{~nm}$

Gambar 4. Kromatogram standar asam amino 50 ppm 
dengan analisis KCKT. Kromatogram standar asam amino dengan konsentrasi 50 ppm (f) dapat dilihat pada Gambar 4. Adapun masing-masing kromatogram sampel G40, GF0, GF20, dan GF40 dapat dilihat pada Gambar 5, 6, 7, 8, dan 9.

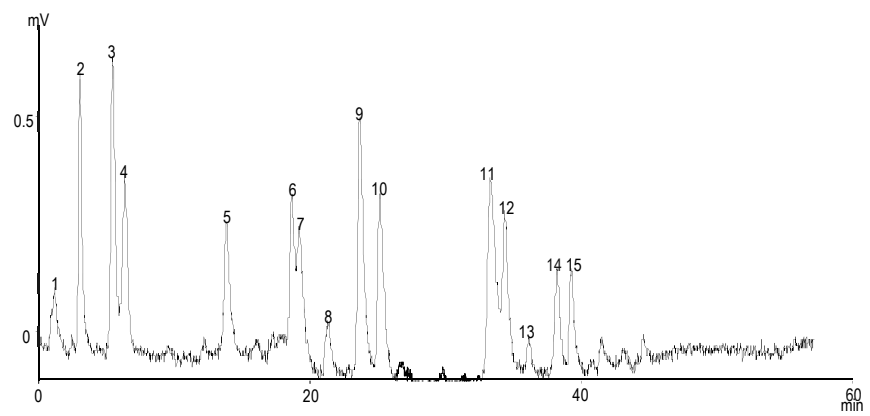

Keterangan: Kondisi analisis sampel gaplek sama dengan kondisi yang digunakan pada Gambar 6

Gambar 5. Kromatogram sampel gaplek

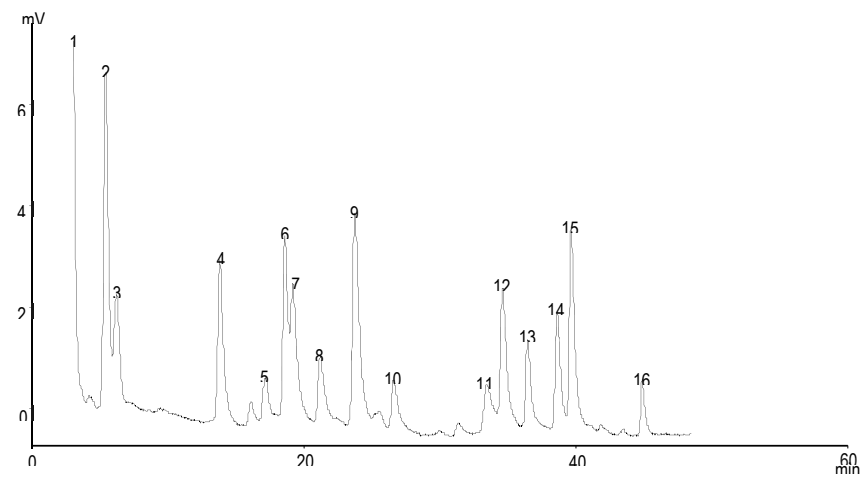

Keterangan : Kondisi analisis sampel gaplek sama dengan kondisi yang digunakan pada Gambar 6

Gambar 6. Kromatogram sampel G40

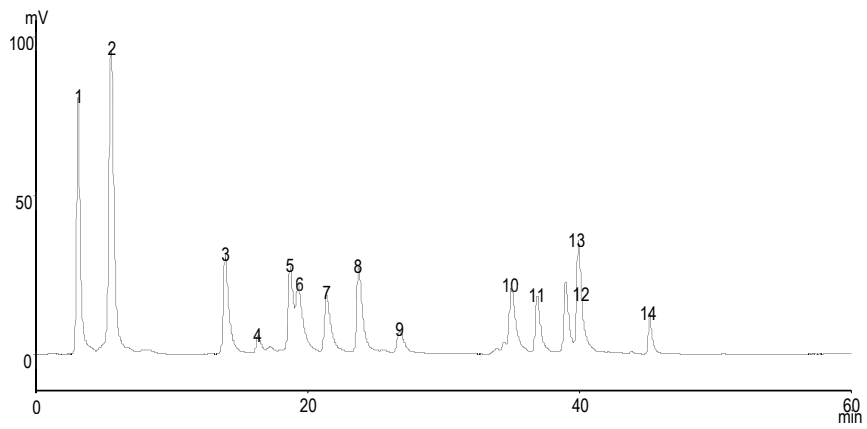

Keterangan : Kondisi analisis sampel gaplek sama dengan kondisi yang digunakan pada Gambar 6

Gambar 7. Kromatogram sampel GF0

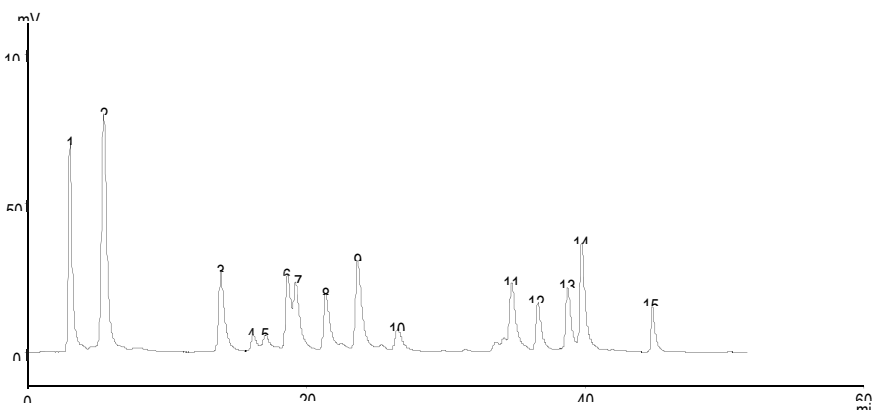

Keterangan: Kondisi analisis sampel gaplek sama dengan kondisi yang digunakan pada Gambar 6

Gambar 8. Kromatogram sampel GF20

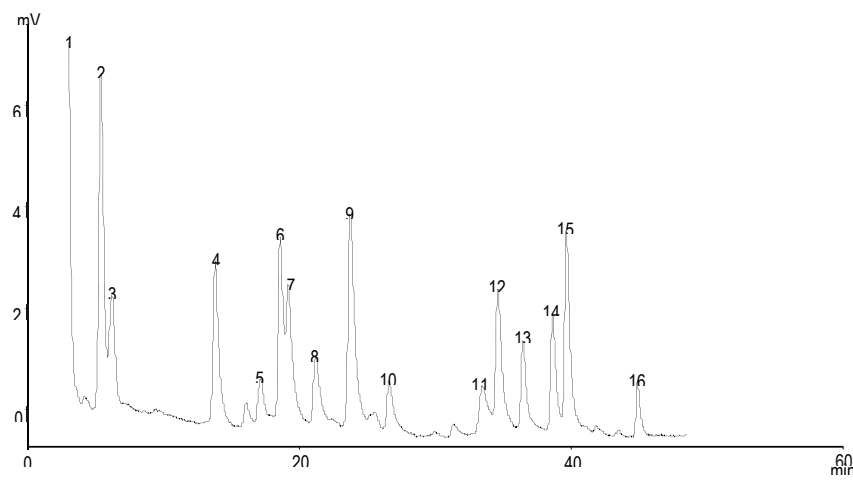

Keterangan: Kondisi analisis sampel gaplek sama dengan kondisi yang digunakan pada Gambar 6

Gambar 9. Kromatogram sampel GF40

Gaplek merupakan suatu bahan pangan lokal yang memiliki kadar protein yang sangat rendah yaitu sebesar $1,46 \%$. Walaupun kadar protein rendah, gaplek memiliki jenis asam amino yang bervariasi, antara lain (dapat dilihat pada Tabel 2): asam aspartat, glutamat, serin, glisin, arginin, alanin, tirosin, valin, isoleusin, dan leusin, namun kadar asam amino yang terkandung dalam gaplek sangatlah kecil bahkan beberapa asam amino seperti asam aspartat, valin, dan isoleusin tidak terkuantitasi. Fortifikasi dengan tepung kedelai yang dilakukan pada gaplek serta adanya proses fermentasi dapat meningkatkan kadar, serta memperkaya jenis asam amino seperti histidin, metionin, dan lisin yang muncul pada sampel GF40. Hasil tersebut dapat dilihat pada Tabel 3. Hasil ini juga selaras dengan penelitian Boonnop dkk. (2009) yang melakukan fermentasi pada singkong dengan Khamir dan Ezekiel dkk. (2010) yang melakukan fermentasi pada kulit singkong dengan Trichoderma viride. Kedua penelitian tersebut menunjukkan adanya peningkatan kadar asam amino selama proses fermentasi. Perubahan asam amino ini diakibatkan oleh mikroorganisme pada ragi yang 
Tabel 3. Perbandingan jenis dan konsentrasi asam amino (ppm) antara gaplek dan GF40 berdasarkan analisis KCKT

\begin{tabular}{|c|c|c|c|c|c|c|c|c|c|c|c|c|c|}
\hline \multirow{2}{*}{ Sampel } & \multicolumn{13}{|c|}{ Asam amino } \\
\hline & Asp & Glu & Ser & Glis & Arg & Ala & Tyr & Val & Ile & Leu & His & Met & Lys \\
\hline Gaplek & t.t. & 5,69 & 9,73 & 14,35 & 13,21 & 8,13 & 12,35 & t.t. & t.t. & 5,75 & t.d. & t.d. & t.d. \\
\hline GF40 & 272,15 & 288,07 & 93,47 & 129,60 & 104,33 & 147,92 & 62,29 & 47,08 & 14,96 & 148,56 & 61,38 & 108,15 & 151,75 \\
\hline
\end{tabular}

Keterangan: t.t. menandakan bahwa asam amino tidak terkuantifikasi; t.d. asam amino tidak terdeteksi; Asp = asam asapartat, Glu = Glutamat, Ser $=$ serin, His $=$ Histidin, Glis $=$ Glisin, Arg $=$ Arginin, Ala $=$ Alanin, Tyr $=$ Tirosin, Met $=$ Metionin, Val $=$ Valin, Ile $=$ Isoleusin, Leu $=$ Leusin, Lys $=$ Lisin

memiliki aktivitas proteolitik yang mampu menguraikan protein menjadi bentuk lebih sederhana yaitu asam amino sehingga kadarnya pun meningkat (Omafuvbe, 2006; Oboh dan Elusiyan, 2007; Mursyid dan Ali, 2005). Selain itu, tepung gaplek terfortifikasi ini juga memiliki keunggulan yaitu adanya asam amino essensial jenis arginin yang tidak dimiliki oleh kedelai.

\section{KESIMPULAN}

Dari penelitian ini maka dapat disimpulkan bahwa fortifikasi gaplek dengan tepung kedelai melalui proses fermentasi dapat meningkatkan kadar protein terlarut dan memperkaya asam aminonya. Peningkatan kadar protein terlarut pada tepung gaplek terfortifikasi tepung kedelai tertinggi didapatkan pada lama waktu fermentasi 40 jam dan diikuti lama waktu fermentasi 20 dan 0 jam, yaitu sebesar 22,86\%, 20,96\%, dan 18,70\% secara berturut-turut.

Asam amino yang teridentifikasi dengan menggunakan metode Kromatografi Lapis Tipis (KLT) pada tepung gaplek terfortifikasi dengan waktu fermentasi 40 jam adalah leusin, metionin, treonin, dan sistein. Adapun berdasarkan hasil analisis Kromatografi Cair Kinerja Tinggi (KCKT), asam amino yang teridentifikasi adalah aspartat, glutamat, serin, histidin, glisin, arginin, alanin, tirosin, metionin, valin, isoleusin, leusin, dan lisin.

\section{DAFTAR PUSTAKA}

AOAC (The Association of Official Analytical Chemist) (1995). Official Methods of Analysis of the Association of Official Analytical Chemist. AOAC, Washington DC.

Adamafio, N.A., Maxwell, S. dan Josephyne, T. (2010). Fermentation in cassava (Manihot esculenta Crantz) pulp juice improves nutritive value of cassava peel. African Journal of Biochemistry Research 4: 51-56.

Amodou, I., Mohamed, T., Kamara, Tidjani, A., Foh, M.B.K. dan Guo-Wei, L. (2010). Physichochemical and nutritional analysis of fermented soybean protein meal by Lactobacillus plantarum Lp6. World Journal Dairy and Food Science 5: 14-118.

Aro, S.O. (2008). Improvement in the nutritive quality of cassava and its by-products through microbial fermentation. African Journal of Biotechnology 7: 4789-4797.

Aro, S.O. dan Aletor, A. (2012). Proximate composition and amino acid profile of differently fermented cassava tuber wastes collected from a cassava starch producing factory in Nigeria. Livestock Research for Rural Development 24(40): 1-8.

Boonnop, K., Wanapat, M., Nontaso, N. dan Wanapat, S. (2009). Enriching nutritive value of cassava root by yeast fermentation. Scientia Agricola (Piracicaba, Braz.) 6: 629-633.

Campbell, A.M. (1992). Flour, flour mixture, and other cereal products. Dalam: Bowers, J. (ed). Food Theory and Application, hal. 270-273. Macmillan Publishing Company, New York.

Chen, C.C., Shih, Y.C., Chiou, P.W.S. dan Yu, B. (2010). Evaluating nutritional quality of single stage- and two stage-fermented soybean meal. Asian-Australasian Journal of Animal Science 23: 598-606.

Ezekiel, O.O., Ogugua, C., Hans, A., Blaschek, P. dan Ezeji, T.C. (2010). Protein enrichment of cassava peel by submerged fermentation with Trichoderma viride (ATCC 36316). African Journal of Biotechonology 9:187-194.

Kementerian Pertanian (2012). Pedoman Umum Program Peningkatan Diversifikasi dan Ketahanan Pangan Masyarakat Badan Ketahanan Pangan Tahun 2012. Kementerian Pertanian, Indonesia.

Li, H., Feng, F.Q., Shen, L.R., Xie, Y. dan Li, D. (2007). Nutritional evaluation of different bacterial douchi. Asia Pacific Journal of Clinical Nutrition 16: 215-221.

Maidawati, N., Hadiataria, N., Supri, Martono, Y., Hartini, S. dan Setiawan, A. (2011). Optimalisasi pembuatan 
tepung gaplek berprotein sebagai upaya mengurangi ketergantungan konsumsi tepung terigu. Prosiding Seminar Nasional Pencitraan dan Pengembangan Produk Lokal Berbasis Kedelai: 25-31. Salatiga, 20 September 2011, Pusat Studi Tempe dan Prodi Kimia Fakultas Sains dan Matematika UKSW.

Mursyid, A. dan Zuprizal (2005). Fermentasi substrat padat pada onggok dengan Aspergillus oryzae: evaluasi kandungan protein dan asam amino, kecernaan dan ketersediaan energi pada ayam broiler. Buletin Peternakan 29: 71-78.

Oboh, G. dan Elusiyan, C.A. (2007). Changes in the nutrient dan anti nutrient content of micro-fungi fermented cassava flour produced from low- and mediumcyanide variety of cassava tubers. African Journal of Biotechnology 6: 2150-2157.

Omafuvbe, B.O. (2006). Effect of salt on the fermentation of soybean (Glycine max) into daddawa using Bacillus subtilis as starterculture. African Journal of Biotechnology 5: 1001-1005.

Onabanjo, O.O., Oguntona, C.R.B., Maziya-Dixon, B., Olayiwol, I.O., Oguntona E.B. dan Dixon A.G.O. (2008). Nutritional evaluation of four optimized cassava-based complementary foods. African Journal of Food Science 2: 136-142.

Onyango, C., Noetzoldb H., Ziemsa A., Hofmanna T., Bleya T. dan Henleb T. (2005). Digestibility and antinutrient properties of acidified and extruded maize-finger millet blend in the production of uji. LWT-Food Science and Technology 38: 697-707.

Onweluzo, J.C. dan Nwabugwu, C.C. (2009). Fermentation of millet (Pennisetum americanum) and pigeon pea (Cajanus cajan) seeds for flour production: effects on composition and selected functional properties. Pakistan Journal of Nutrition 8: 737-744.

Purwoko dan Handajani (2007). Kandungan protein kecap manis tanpa fermentasi moromi hasil fermentasi Rhizopus oryzae dan $R$. oligosporus. Jurnal Ilmiah Biodiversitas 8: 223-227.

Rohner, F. (1991). Food Chemistry, Part 3: ChromatographyEnzymatic Test Methods. Leybold Didactic $\mathrm{GmbH}$, Jerman.

Rosallina (2011). Konsumsi tepung terigu nasional melambat. http://www.tempo.co/read/news/2011/10/27/0903 63609/Konsumsi-Tepung-Terigu Nasional-Melambat. [7 Desember 2011].

Rukmana, R. (1997). Ubi Kayu: Budidaya dan Pascapanen. Kanisius, Yogyakarta.

Ugwuona, F.U., Ogara, J.I. dan Awogbenja, M.D. (2012). Chemical and sensory quality of cakes formulated with wheat, soybean and cassava flours. Indian Journal of Life Science 1: 1-6. 